\title{
STUDENT ATTITUDES TOWARDS MIGRANTS IN THE PRE-COVID-19 PERIOD
}

\author{
Anita Blagojević, PhD, Associate Professor \\ Faculty of Law Osijek \\ Stjepana Radića 13, 31000 Osijek \\ ablagoje@pravos.hr
}

\author{
Gordana Horvat, MSW, Teaching and Research Assistant \\ Faculty of Law Osijek \\ Stjepana Radića 13, 31000 Osijek \\ ghorvat@pravos.hr
}

\begin{abstract}
There is no doubt that prior to Covid-19 outbreak the issue of migration had been one of the top priorities across the European Union, especially after so-called "refugee crisis" of 20152017. However, the situation rapidly changed since Covid-19 outbreak, when migration has fallen off the radar as a political issue. The aim of this paper is to analyse students' attitudes towards migrants, in the period before COVID-19, and our initial thesis is that the fact that attitudes towards migrants are rooted in individual values and when established can be resistant to change.

The paper consists of three parts. In the first part of the paper, we give an overview of available reports on the impact of Covid-19 to public attitudes towards migrants. Although is too early to make some general conclusions about it, the surveys made so far show that external factors, such as Covid-19, does not make important changes to public attitudes towards migrants. Having this in mind, in the second part of the paper we present the results of our research which was developed as a part of the project "Creating Welcoming Communities" of the Association "MI". The purpose of this research was to identify the attitudes of students of the Faculty of Law Osijek for the acceptance and integration of migrant into society. The target group of survey participants covered by the research was defined so as to include students of different levels (Intergrated Undergraduate and Graduate Study Programme, Professional Administrative Study Programme, University Undergraduate Study of Social Work) and the sample of students included 300 persons. Finally, in the third part of the paper we give a synthesis of our research and a review of the topic from the perspective of human rights and social work in the community.
\end{abstract}

Keywords: Covid-19, European Union, human rights, migrants, public attitudes, social work 


\section{INTRODUCTION}

There is no doubt that prior to Covid-19 outbreak the issue of migration had been one of the top priorities across the European Union, especially after so-called "refugee crisis" of 2015-2017. However, the situation rapidly changed since Covid-19 outbreak, when migration has fallen off the radar as a political issue.

Not surprisingly, the results of the Standard Eurobarometer survey of summer $2020^{1}$ show that the main concern of the Europeans is the economic situation, while the state of Member States' public finances and immigration (previously main concern at the EU level) share the second place. However, the analysis of the main concerns at national level shows that mentions of immigration, which ranks seventh place, are at their lowest level over the past six years, and some other issue became priorities in this context (the economic situation, health, unemployment, rising prices and cost of living, the environment and climate change, government debt). Of course, when it comes to immigration issue, there are considerable differences between Member States. This issue ranks first in ten countries, particularly in Malta, Cyprus, Estonia and Hungary, while in Slovenia and Bulgaria is the second most mentioned issue. Results for Croatia show that the most important issues, at the moment, facing the EU for the Croats are the economic situation and health, while the state of public finances and immigration share the third place. However, when it comes to issues facing Croatia, immigration ranks seventh place, while the most important issues are the economic situation, unemployment and health.

The aim of this paper is to analyse what students' attitudes were before the pandemic towards migrants, while during the pandemic the public focused almost entirely on the pandemic. Main hypothesis is that public attitudes towards migrants are created based on identification factors. This is because the attitudes towards migrants are rooted in individual's values and once established they can be resistant to change.

The paper consists of three parts. In the first part of the paper we give an overview of available reports and researches on the impact of Covid-19 to public attitudes towards migrants. Although is too early to make some general conclusions about it, the surveys made so far show that external factors, such as Covid-19, does not make important changes to public attitudes towards migrants. Having this in

Standard Eurobarometer survey of summer 2020 was carried put between 9 July and 26 August 2020 in the 27 EU Member States, and also in the United Kingdom and in five candidate countries. Standard Eurobarometer 93, Summer 2020, Firts results: Public opinion in the European Union, available on: [https://data.europa.eu/euodp/en/data/dataset/S2262_93_1_93_1_ENG], Accessed 15 January 2021. 
mind, in the second part of the paper we present the results of our research which was developed as a part of the project "Creating Welcoming Communities" of the Association "MI". The purpose of this research was to identify the attitudes of students of the Faculty of Law Osijek for the acceptance and integration of migrant into society. The target group of survey participants covered by the research was defined so as to include students of different levels (Intergrated Undergraduate and Graduate Study Programme, Professional Administrative Study Programme, University Undergraduate Study of Social Work) and the sample of students included 300 persons. Finally, in the third part of the paper we give a synthesis of our research and a review of the topic from the perspective of human rights and social work in the community.

\section{RESEARCHES ON PUBLIC ATTITUDES TOWARDS MIGRANTS}

Academic research has a long history of attempting to answer what determines public attitudes towards migrants. And yet, in spite of this academics from different disciplines, and also policy makers, have not yet reached a consensus about the "drivers of attitudes" towards migrants.

An analysis of the extensive literature on attitudes towards migrants shows that most of the theories focuses on social-psychological, sociodemographic and socioeconomic explanations. Also, it is important to emphasize that attitudes towards migrants "are shaped by both the attributes of the country and the characteristics of individuals residing in the country."

In its comprehensive comparative review of theories and research of public attitudes towards migrants Ceobanu and Escandell ${ }^{3}$ highlighted the existence of two theories of attitudes towards migrants: first, individual-level theories, focusing on the role of socioeconomic correlates and self-interests, identities and values and contact with out-group members, and second, contextual-level theories, focusing on structural conditions which try to answer why particular groupings of people develop certain views towards out-group members.

In its review of available literature on the subject Davidov and Semyonov conclude that researchers underscores a series of country-level attributes and individual-level characteristics that account for shaping attitudes towards migrants.

2 Davidov, E.; Semyonov, M., Attitudes toward immigrants in European societies, International Journal of Comparative Sociology, Vol. 58, No. 5, 2017, p. 361.

3 Ceobanu, A. M.; Escandell, X., Comparative Analyses of Public Attitudes Toward Immigrants and Immigration Using Multinational Surve Dana: A Review of Theories and Research, Annual Review of Sociology, Vol. 36, 2010. 
When it comes to country-level attributes, they found that the existing literature focuses on the size of the migrant population, economic conditions, the political climate in the country, welfare and migrant integration policies, state support of religious practices, frequency of terrorist attacks and (negative) media coverage on migrant-related news. ${ }^{4}$ Attitudes towards migrants are also associated with a series of individual-level characteristics, such as fear of competition, nationalism, racial prejudice, conservative ideologies and basic human values. ${ }^{5}$

Markaki and Longhi analysed the theoretical and empirical contributions to the literature on anti-migrants attitudes and found that theories on the formation of attitudes towards migrants can be divided into two strands: first, that includes social-psychological, affective or ideological explanations, and second, that includes rational-based group and labour market competition theories. ${ }^{6} \mathrm{With}$ regard to the empirical implementation, they found that attitudes towards migrants (and minority groups in general) can be classified into three groups: cognitive (which relates to stereotypes), affective (which relates to prejudices) and behavioural (which relates to discrimination). ${ }^{7}$

Baričević and Koska found that anti-migration attitudes in liberal democracies can be explained with cultural (the fear of endangering of domestic culture), economic (the pressure on labour market and social status) and security framework (terrorist attacks and an increase in the general crime level). ${ }^{8}$ They also argue that significant portion of these assumptions is relevant in Croatian public context. ${ }^{9}$

An indeed, the research conducted so far in Croatia show that the attitudes towards migrants are mainly negative, coloured by numerous prejudices and fears. In its research on attitudes of adult Croatian citizens towards migrant workers Čačić Kumpes, Gregurović and Kumpes found that the main "drivers of attitudes" towards migrants are socioeconomic and sociocultural factors, i.e. that potential migrant workers are seen to a large extent both as socioeconomic and sociocultural threat, and therefore the respondents (on average) expressed unwillingness for closer contacts with them. ${ }^{10}$ Gregurović, Kuti and Župarić-Iljić analysed the

\footnotetext{
4 Davidov; Semyonov, op. cit., note 2, p. 361.

5 Ibid.

6 Markaki, Y.; Longhi, S., What determines Attitudes to Immigration in European Countries? An Analysis at the Regional Level, Norface migration, Discussion Paper No. 32, 2012, p. 4.

Ibid., p. 6.

8 Baričević, V.; Koska, V., Stavovi i percepcije domaće javnosti o nacionalnim manjinama, izbjeglicama $i$ migrantima, Centar za mirovne studije, Zagreb, 2017, p. 14-15.

$9 \quad$ Ibid., p. 15.

10 Čačić Kumpes, J.; Gregurović, S.; Kumpes, J., Migracija, integracija i stavovi prema imigrantima u Hrvatskoj, Revija za sociologiju, Vol. 42, No. 3, 2012.
} 
attitudes towards migrant workers and asylum seekers in Eastern Croatia (OsijekBaranja and Vukovar-Srijem counties) and they results indicated significant perceptions of migrant workers as within the dimension of cultural threat, along with the expression of a considerable degree of social distance towards migrants. In addition, they found that asylum seekers are perceived as a security and economic threat. ${ }^{11}$ The research made by Ajduković, Bakić, Stanković and Matić confirms the existence of prejudices towards asylum seekers and a moderate level of perceived threat from asylum seekers. ${ }^{12}$

Without any doubt, the Covid-19 outbreak presents a powerful test of attitudes towards migrants. With pandemic monopolising attention and public debates, "it appears that the salience of immigration issues has decreased in public opinion."13 However, the devastating impact of the pandemic on nations and individuals and the reactions to the pandemic led to increased feelings of threat, lack of control, competition and uncertainty that could have deleterious effects on attitudes towards migrants and could lead to a surge in xenophobia and anti-migrant attitudes. ${ }^{14}$ As stated by Gregurović and others, even though migration issues have been suppressed by health and economic issues, "the possibility of instrumentalisation anti-immigrant attitudes for political purposes has not disappeared."15

In his analysis for the International Organization for Migration Gaudagno states that the pandemic "has been weaponized to spread anti-migrant narratives and call for increased immigration control and reduction of migrants' rights." ${ }^{16}$ In this context he highlighted that the pandemic has triggered episodes of xenophobia directed towards internal migrants in China and Asian migrants in countries all

11 Gregurović, M.; Kuti, S.; Župarić-Iljić, D., Stavovi prema migrantskim radnicima i tražiteljima azila u istočnoj Slavoniji: dimenzije, odrednice i razlike, Migracijske i etničke teme, Vol. 32, No. 1, 2016.

12 Ajduković, D.; Bakić, H.; Stanković, N.; Matić, J., Odnos mladih prema integraciji azilanata, in: Ćubela Adorić, V. et al. (eds.), 25. godišnja konferencija hrvatskih psihologa - Psihologija u promociji i zaštiti ljudskih prava i društvene pravednosti - Sažetci priopćenja, Zagreb, 2017.

13 OECD, Policy Responses to Coronovirus (COVID-19), What is the impact of the COVID-19 pandemic on immigrants and their children?, 19 October 2000, p. 21, availble on: [https://www.oecd.org/coronavirus/policy-responses/what-is-the-impact-of-the-covid-19-pandemic-on-immigrants-and-their-children-e7cbb7de/], Accessed 5 April 2021.

14 Esses, V. M.; Hamilton, L. K., Xenophobia and anti-immigrant attitudes in the time of COVID-19, Group Processes and Integroup Relations, Vol. 24, No. 2, 2012, available on: [https://journals.sagepub.com/doi/pdf/10.1177/1368430220983470], Accessed 4 April 2021.

15 Gregurović, M. et al., Pandemic Management Systems and Migration, Migracijske i etničke teme, Vol. 36, No. 2-3, 2020, p. 219.

16 Gaudagno, L., Migrants and the COVID-19 pandemic: An initial analysis, Internation Organization for Migration, 2020, p. 12, available on: [https://publications.iom.int/system/files/pdf/mrs-60.pdf], Accessed 5 April 2021. 
over the world. ${ }^{17}$ Vertovec thinks that it is clear that Covid-19 worsens xenophobia and racism worldwide and states that xenophobic sentiments related to the pandemic were evident in political sphere as well, i.e. in Trump's assertions about migrants and calling the new coronavirus as a "Chinese virus", in Salvini's accusations against African migrants in Italy and in Orban's linkage of coronavirus with illegal migrants in Hungary. ${ }^{18}$ White warns that the analysis of the histories of international responses to epidemic events show that the part of this history is the role of xenophobic responses to infectious disease threats. ${ }^{19}$

On the other hand, Dennison and Geddes do not assume that the pandemic will necessarily cause more negative attitudes towards migrants. They based their argument on two premises: first, on the general trend in attitudes towards migrants across Europe in $21^{\text {st }}$ century (which is proven in mentioned Eurobarometer survey), and second, on the scientific researches which has shown the importance of early life experience in the formation of social and political attitudes. They argument that "once established, attitudes can be resistant to change and also become an important aspect of a person's identity to which he or she feels an emotional attachment." ${ }^{20}$

Although is too early to make some general conclusions about it, we also suggest that Covid-19 does not and will not make important changes to public attitudes towards migrants. This is because the attitudes towards migrants are rooted in individual's values and once established they can be resistant to change. Additionally, we have to bear in mind that even major external factors as the 2008 financial crisis and the so-called migration crisis in 2015 did not lead to deviation from the long-term trend of more, not less favourable attitudes towards migration in Europe in the $21^{\text {st }}$ century. ${ }^{21}$

Having this in mind, in the next part of the paper we present the results of our research that was developed as a part of the project "Creating Welcoming Communities" of the Association "MI".

$17 \quad$ Ibid., p. 11.

18 Vehovec, P., Covid-19 and enduring stigma: The corona pandemic increases xenophobia and exclusion worldwide, Max-Planck-Gesellschaft, April 27, 2020, available on: [https://www.mpg.de/14741776/ covid-19-and-enduring-stigma], Accessed 5 April 2021.

19 White, A. I. R., Historical linkages: pidemic threat, economic ris, and xenophobia, The Lancelot, Vol. 395, 2020, available on: [https://www.thelancet.com/journals/lancet/article/PIIS0140-6736(20)30737-6/ fulltext], Accessed 6 April 2021.

20 Dennison, J.; Geddes, A., Why COVID-19 does not necessarily mean that attitudes towards immigration will become more negative, International Organization for Migration, 2020, p. 2, available on: [https:// publications.iom.int/books/covid-19-and-transformation-migration-and-mobility-globally-why-covid-19-does-not-necessarily], Accessed 5 April 2021.

$21 \quad$ Ibid., p. 7. 


\section{OBJECTIVE AND PROBLEM OF THE RESEARCH}

The main goal of the research was to determine the attitudes of law and social work students towards migrants regarding students' identity characteristics. In accordance with the goal, the research problem was defined in relation to the identity characteristics of students, and the research tried to determine: whether there is a difference in attitudes between students of social work and law at the Faculty of Law in Osijek; whether there is a difference in attitudes towards gender, political orientation and religiosity. The goals and the research problem formed the research starting point based on the hypotheses: H1. Female respondents have more positive attitudes toward migrants and refugees than male respondents; $\mathrm{H} 2$. The field of social work science has a greater impact on the positive attitudes of respondents, compared to the field of law; H3. Political orientation on the right influences more negative attitudes towards migrants and refugees; H4. Respondents who are more religious have more positive attitudes toward migrants and refugees.

\subsection{Research procedure and methodology}

The research was conducted as part of the project activities of the Association "MI" from Split through the project "Creating welcoming communities", with financial support and cooperation with the UNHCR and the UN Agency for Refugees Representation in Croatia. Student volunteers, a total of 21 students, participated in the survey of students of the Faculty of Law in Osijek, including all academic years: undergraduate, integrated, or professional studies. The Faculty of Philosophy in Split, the Faculty of Philosophy in Rijeka and the Faculty of Law in Osijek participated in the joint creation of the questionnaire and research so that they could get a comparison at the regional level and map general students' attitudes and knowledge. The survey questionnaire was approved by the Ethics Committee of the Faculty of Philosophy in Split in May 2019. The research was conducted during the months of May and June 2019 at the Faculty of Law in Osijek in a way that respondents filled out a printed survey questionnaire. Respondents' participation was voluntary and anonymous. Before starting the examination, the aim and purpose of the research were explained to the respondents, the reasons and benefits of the examination and the information obtained were explained. The research was conducted as a quantitative research in which the survey questionnaire method was used for the purpose of collecting statistical data. ${ }^{22}$

22 Halmi, A., Temelji kvantitativne analize u društvenim znanostima - Kvantitativni pristup socijalnom radu, Alinea, Zagreb, 2013. 


\subsection{Respondents}

The research was conducted at the Faculty of Law in Osijek. Out of the total population of law students (1361 students) and social work (141 students), a total of 239 students of the Faculty of Law in Osijek participated in the survey. The total number of respondents in law studies includes full-time and part-time students of integrated law studies and professional studies. Out of a total number of law students, range in age is from 20 to 38 years of age. Social work students are undergraduate students, as graduate studies are just being formed, between the ages of 19 and 50, and include full-time and part-time students.

\subsection{Data collection methods and data processing}

For the needs of the research, a specially constructed survey questionnaire was used for this research. The survey questionnaire consisted of three parts. At the beginning of the questionnaire, sociodemographic data were collected: gender, age, place of residence, religion, political orientation and field of study. The first part of the questionnaire consists of twenty items and measures students' attitudes towards immigrants and refugees including: criteria for accepting migrants (culture, language, religion and political culture), willingness to help and acceptance, perception of impact on cultural values of our society, attitudes about quality life of migrants, placing barbed wire on borders, perception of security threats, economic impact and reasons for accepting migrants and refugees. The second part of the questionnaire consists of four particles and focuses on the perceived area and knowledge of students on the topic, while the third part of the six-part questionnaire, focuses on the perception of social distance. This paper will present data from the first part of the research related to students' attitudes towards immigrants and refugees.

The questions are constructed as a dichotomous (yes/no), nominal scale (choice of answers) or interval scale or Likert scale (I disagree, mostly disagree, neither agree nor disagree, mostly agree, agree). The part of the questionnaire, which is presented in this paper, and refers to the attitudes of students, has 20 particles and slightly lower reliability (Table 1 ) of 0.649 Cronbach's alpha ${ }^{23}$. The collected data were processed by the statistical program SPSS 22, descriptive statistics, variability, frequency of responses and chi-square test for comparison of constructs. The chi-square test was used for the independence of the research question of one independent variable and one dependent variable ${ }^{24}$. A set of predictors of identity

23 DeVellis, R. F., Scale Development: Theory and Applications, Applied Social Research Methods Series, Vol. 26. Newbury Park, CA: Sage Publications, 1991.

24 Gravetter, F.J.; Wallnau, L.B., Statistics for the Behavioral Sciences, [6th ed.] Australia; Belmont, CA: Thomson/Wadsworth, 2004. 
characteristics (socio-demographic variables) and a set of responses defining attitudes towards immigrants and refugees were observed.

Table 1: Cronbach's alpha - statistical reliability

\section{Reliability Statistics}

\begin{tabular}{|l|l|l|}
\hline Cronbach's Alpha & Cronbach's Alpha Based on Standardized Items & N of Items \\
\hline .624 & .649 & 20 \\
\hline
\end{tabular}

Participation in the trial was completely anonymous and voluntary. During the research, the respondents were acquainted with the aim and purpose of the research with an explanation of what the obtained data will be used for. All participants were informed about the anonymity and confidentiality of the collected data and the way of presenting the results. The results are presented in tables and graphs for a clearer presentation of the obtained data.

\section{RESULTS AND DISCUSSION}

The research was conducted at the Faculty of Law in Osijek, as one of the faculties within the J.J. Strossamyer University in Osijek, with the aim of determining the attitudes of law and social work students towards immigrants and refugees. With regard to social work, as an aiding practice and social science, and law as an indispensable scientific segment of each practice, the research sought to obtain a deeper picture of students' attitudes in order to create the necessary and clear basis for the educational process in human rights and anti-discrimination practice.

\subsection{Socio-demographic characteristics of respondents and results}

The number of students, full-time and part-time, at the Faculty of Law in Osijek in 2019 was 1502 students, of which 1361 were law students and 141 social work students. Of the total number of students (1502) at the faculty level, 239 students (Table 2) participated in the survey or 17.6\%. 167 law students participated, which is $12.3 \%$ of the total population of law students. Out of the total population of social work students (141 students), 51.8\% of students in this field participated in the survey. In the sample, out of the total number of respondents (239), respondents in the field of law make up $69.9 \%$ or 167 respondents and 73 respondents are social work students or $21.8 \%$. 
Table 2: Distribution of students by study fields

Study fields

\begin{tabular}{|l|l|l|l|l|l|}
\hline \multicolumn{2}{|c|}{} & Frequency & Percent & Valid Percent & Cumulative Percent \\
\hline \multirow{7}{*}{ Valid } & Law & 167 & 69.9 & 69.9 & 69.9 \\
\cline { 2 - 6 } & Social work & 72 & 30.1 & 30.1 & 100.0 \\
\cline { 2 - 6 } & Total & 239 & 100.0 & 100.0 & \\
\hline
\end{tabular}

Of the total number of respondents, full-time and part-time students in both fields, 48 male respondents or $20.1 \%$ and 191 female respondents or $79.9 \%$ participated (Table 3). It can be seen that there are significantly fewer male respondents compared to females, and the difference is also visible between study fields, so there are more male students studying law (17.95) compared to the study field of social work (2,09\%). Since the establishment of the Social Work Studies in Osijek in 2017, the enrollment of male candidates in the past four generations has averaged 3-5 students in relation to the total enrollment quota of full-time and part-time students, which is 70 students. We can relate this fact to the data of the new concept of division of labor today which brings new challenges ${ }^{25}$. The gender division In Croatia is present and women are mostly employed in sectors where a larger role of emotional work is needed ${ }^{26}$. There is a growing need for an emotional role in the workplace in a way that the feelings of the worker are adjusted to the service that the worker performs ${ }^{27}$. It is women who are most often employed in helping professions, which can be related to the number of male students in the study program of social work.

Table 3: Distribution of respondents by gender

Gender

\begin{tabular}{|l|l|l|l|l|l|}
\hline \multicolumn{2}{|c|}{} & Frequency & Percent & Valid Percent & Cumulative Percent \\
\hline \multirow{3}{*}{ Valid } & Male & 48 & 20.1 & 20.1 & 20.1 \\
\cline { 2 - 6 } & Female & 191 & 79.9 & 79.9 & 100.0 \\
\cline { 2 - 6 } & Total & 239 & 100.0 & 100.0 & \\
\hline
\end{tabular}

25 Castells, M.; Cardoso, G., The Network Society. From Knowledge to Policy, Washington, DC: Johns Hopkins Center for Transatlantic Relations, 2005.

26 Dobrotić, I., Posao ili obitelj? Uloga i važnost politika uskladivanja obiteljskih obaveza i plaćenog rada. Kerschoffset d.o.o., Zagreb, 2017.

27 Mali, J., Starost, emocije in emocionalno delo v domovih za stare, Socialno delo, Vol. 41, No. 6, p. $317-$ 323, 2002. 


\subsection{Examining attitudes towards migrants and refugees}

The conducted questionnaire, which determined the overall attitudes towards migrants and refugees, consisted of twenty items arranged in scales that define the level of agreement with individual statements, and define respondents' attitudes about migrants and refugees in the segment of assistance, access to migrants, impact on culture, security and economic aspect. The scale used is of the Likert type in which for each question it was necessary to select a degree of agreement of 1-5 whereby it was necessary to recode three questions from 5-1. After recoding, the summed results on individual particles show the total result (from a minimum of 10 to a maximum of 48 points) of the respondents' attitudes, with a smaller value showing a more negative attitude.

Table 4: Overview of attitudes towards migrants and refugees of all respondents Attitudes towards migrants and refugees

\begin{tabular}{|l|l|l|l|l|l|}
\hline \multicolumn{2}{|c|}{} & Frequency & Percent & Valid Percent & Cumulative Percent \\
\hline Valid & Medium negative attitude & 40 & 16.7 & 16.7 & 16.7 \\
\cline { 2 - 6 } & Neutral attitude & 87 & 36.4 & 36.4 & 53.1 \\
\cline { 2 - 6 } & Medium positive attitude & 93 & 38.9 & 38.9 & 92.1 \\
\cline { 2 - 6 } & Positive attitude & 19 & 7.9 & 7.9 & 100.0 \\
\cline { 2 - 6 } & Total & 239 & 100.0 & 100.0 & \\
\hline
\end{tabular}

The result at the level of all respondents shows that no respondent has a negative attitude, while $38 \%$ of respondents have a medium positive attitude and slightly less $36 \%$ a neutral attitude (Table 4). According to the interpreted results, we conclude that the attitudes of law and social work students are more positively oriented.

Table 5: Descriptive analysis of attitudes towards migrants and refugees of all respondents

Statistics

\begin{tabular}{|l|l|l|}
\hline \multirow{2}{*}{ Mean } & Valid & 239 \\
\cline { 3 - 3 } & Missing & 0 \\
\hline Median & 31.40 \\
\hline Mode & 31.00 \\
\hline Std. Deviation & $30^{\mathrm{a}}$ \\
\hline \multirow{3}{*}{ Percentiles } & 25 & 5.560 \\
\cline { 3 - 3 } & 50 & 27.00 \\
\hline & 75 & 31.00 \\
\hline
\end{tabular}

a. Multiple modes exist. The smallest value is shown 
The total number of respondents 239 , both sexes achieved a result in the questionnaire and particles that measure attitudes (minimum 10 to maximum 48 points) ranging from 18 to 45 points. The variation width is 27 , the standard deviation $\mathrm{SD}$ is 5.56 while the median is 31 and the mode is 30 . The arithmetic mean is $\mathrm{M}=$ 31.40. It can be seen that the results according to the expressed frequency tend to the category of neutral to moderately positive attitudes of the respondents, while the median and mode in relation to the arithmetic mean are on the left and show a slight deviation from the normal distribution and slightly asymmetric distribution to the left (Table 5). In the attitudes about the quality of life of migrants and refugees, all respondents, regardless of study and gender, are of the same opinion that all those found in the territory of the Republic of Croatia should have a higher level of quality of life, which includes accommodation, food, hygiene and health care and over half of them $58 \%$ say it is necessary. All immigrants, regardless of the reason and the way they found themselves in the Republic of Croatia, are people in need and need help. A total of $48 \%$ of respondents agree with this statement, while $28 \%$ of respondents neither agree nor disagree, and almost $24 \%$ of respondents generally disagree or disagree. There are no significant deviations in the study areas, as well as the question of whether immigrants have an impact on the cultural and traditional values of Croatian society, where the number of respondents is divided, almost half say yes, while the other half say no. Half of the respondents who claim that there is an impact think that it is negative $(26 \%)$ or neither positive nor negative (23\%). One of the issues that also symbolically depicts the barrier and resistance to migrants is the issue of placing barbed wire as a solution to stop illegal immigration, where the difference between law and social work study programs is significant. Respondents in the legal field, $28 \%$ of them, believe that they agree or mostly agree with the use of barbed wire, $32 \%$ of them do not agree with the above, while $23 \%$ neither agree nor disagree. Respondents of social work studies, $85 \%$ of them disagree or mostly disagree. Uniformity of attitudes occurs in attitudes regarding the security of Croatian citizens and their vulnerability to the arrival of immigrants, where, out of the total number of respondents, $36 \%$ mostly agree or agree that the security of Croatian citizens is endangered while $32 \%$ generally disagree. The public, as well as the respondents, were exposed to media influence and the media that reported on migrant routes, the situation on the ground, the columns of migrants arriving, and the assistance provided to them. Respondents' perception of the way media reporting showed a difference in the attitudes of law students who mostly think, except too negatively $32 \%$, that they do not know or too positively $22 \%$ and social work students who do not see media reporting as positive and neutral and objective but mostly negative $62 \%$. Respondents, overall, agree on the main reasons why immigrants choose to leave their own country, with $30 \%$ of respondents citing an economic reason 
while war and political insecurity were chosen by $54 \%$ of respondents. Likewise, respondents state that immigrants are a burden on Europe's economic development, $55 \%$ of them while $34 \%$ are neutral.

\subsubsection{Respondents' attitudes towards migrants and refugees in relation to gender}

The difference in attitudes towards migrants and refugees in relation to gender shows statistical significance. Women show more positive or moderately positive attitudes towards migrants and refugees $52.4 \%$ or 100 respondents out of 191 in total in the sample, while men express more moderately negative or neutral attitudes, a total of 36 respondents out of 48 or $75 \%$ of which $35 \%$ are oriented medium negative attitude (Table 6).

Table 6: Overview of respondents' attitudes towards gender and descriptive statistics

Gender * Attitudes towards migrants and refugees Crosstabulation

\begin{tabular}{|c|c|c|c|c|c|c|}
\hline & \multicolumn{4}{|c|}{ Attitudes towards migrants and refugees } & \multirow[b]{2}{*}{ Total } \\
\hline & & $\begin{array}{l}\text { Medium nega- } \\
\text { tive attitude }\end{array}$ & $\begin{array}{l}\text { Neutral } \\
\text { attitude }\end{array}$ & $\begin{array}{l}\text { Medium posi- } \\
\text { tive attitude }\end{array}$ & $\begin{array}{l}\text { Positive } \\
\text { attitude }\end{array}$ & \\
\hline \multirow{2}{*}{ Gender } & Male & 17 & 19 & 10 & 2 & 48 \\
\hline & Female & 23 & 68 & 83 & 17 & 191 \\
\hline \multicolumn{2}{|l|}{ Total } & 40 & 87 & 93 & 19 & 239 \\
\hline
\end{tabular}

To obtain statistical significance between respondents by gender and in relation to attitudes towards migrants and refugees, and in accordance with the first hypothesis, the chi-square test was used for one independent variable (gender) and one independent variable (attitudes). The chi-square independence test showed a significant difference between gender and attitudes towards migrants and refugees $(\mathrm{p}$ $<0.05$ ) with the obtained values (Table 6$)$ of $\mathrm{c} 2(1, \mathrm{n}=239)=0.281, \mathrm{p}=0.000$, fi $=0.28$ (Table 8 ). The correlation coefficient fi is 0.28 , which according to Cohen's criteria $^{28}$ is the mean strength of the influence between the two variables. According to the results, there is a statistically significant difference in attitudes towards migrants and refugees between men and women.

28 Cohen J., Statistical Power Analysis for the Behavioral Sciences, NY: Routledge Academic, New York, 1988. 
Table 7: Overview of statistical data on respondents' attitudes towards gender

Chi-Square Tests

\begin{tabular}{|l|l|l|l|}
\hline & Value & df & Asymp. Sig. (2-sided) \\
\hline Pearson Chi-Square & $18.816^{\mathrm{a}}$ & 3 & .000 \\
\hline Likelihood Ratio & 17.600 & 3 & .001 \\
\hline $\begin{array}{l}\text { Linear-by-Linear Asso- } \\
\text { ciation }\end{array}$ & 16.109 & 1 & .000 \\
\hline N of Valid Cases & 239 & & \\
\hline
\end{tabular}

1 cells $(12.5 \%)$ have expected count less than 5 . The minimum expected count is 3.82 .

Table 8: Display of symmetric measure

Symmetric Measures

\begin{tabular}{|l|l|l|l|}
\hline \multicolumn{2}{|l|}{} & Value & Approx. Sig. \\
\hline Nominal by Nominal & Phi & .281 & .000 \\
\cline { 2 - 4 } & Cramer's V & .281 & .000 \\
\hline N of Valid Cases & 239 & \\
\hline
\end{tabular}

According to available research conducted in Croatia that includes gender as an identity determinant in the creation of attitudes, research ${ }^{29}$ noted that women are more willing to help and have a more positive attitude towards migrants and refugees. The authors ${ }^{30}$ of a survey conducted among young people also show that male respondents perceive migrants and refugees more as a social and cultural threat compared to female respondents. Based on the obtained results, it is necessary to point out the possible methodological lack of research, given that the number of male respondents is significantly lower (48) compared to the number of female respondents (191). According to the obtained result, gender, as one of the identity determinants of individuality, can be related to the creation of certain attitudes according to the authors Ceoban and Escandell ${ }^{31}$ (2010) who defined the theory focused on the identity and values of each individual as a factor in creating attitudes.

29 Ajduković, D. et. al., Izazovi integracije izbjeglica u hrvatsko društvo: stavovi gradana i pripremljenost lokalnih zajednica, ACT Printlab d.o.o., Zagreb, 2019.

30 Kalebić Maglica, B.; Švegar, D.; Jovković, M. , Odnos osobina ličnosti, efekta okvira i stavova prema migrantima, Društvena istraživanja, Vol. 27, No. 3, 2018, p. 495-517.

31 Ceobanu, A. M.; Escandell, X., Comparative Analyses of Public Attitudes Toward Immigrants and Immigration Using Multinational Surve Dana: A Review of Theories and Research, Annual Review of Sociology, Vol. 36, 2010. 


\subsubsection{Attitudes of respondents towards migrants and refugees in relation to the field of study}

The profession of social work is oriented towards facilitating the integration of migrants into the community, and strongly promotes the right to diversity, which is one of the key values of the Code of Ethics for Social Workers ${ }^{32}$. Legal science, as a social science, is an indispensable part of social work and is important in assessing the rights that groups of migrants and refugees have in helping these groups from a legal point of view. . At the Faculty of Law in Osijek, the study fields of law have existed for many years, while the study field of social work began with the implementation of the study program in 2017. Courses focusing on human rights, social justice, advocacy and anti-discrimination practice are conducted in both fields of study as an integral part of the study curriculum. Out of a total of 239 respondents, $69.9 \%$ are respondents in the field of law and $30.1 \%$ are respondents in the field of social work.

Table 9: Overview of statistical data on respondents' attitudes towards field of study

Chi-Square Tests

\begin{tabular}{|l|l|l|l|}
\hline & Value & df & Asymp. Sig. (2-sided) \\
\hline Pearson Chi-Square & $54.205^{\mathrm{a}}$ & 3 & .000 \\
\hline Likelihood Ratio & 59.212 & 3 & .000 \\
\hline Linear-by-Linear Association & 51.545 & 1 & .000 \\
\hline N of Valid Cases & 239 & & \\
\hline
\end{tabular}

0 cells $(0.0 \%)$ have expected count less than 5 . The minimum expected count is 5.72 .

Table 10: Display of symmetric measure

Symmetric Measures

\begin{tabular}{|l|l|l|l|}
\hline \multicolumn{2}{|c|}{} & Value & Approx. Sig. \\
\hline \multirow{2}{*}{ Nominal by Nominal } & Phi & .476 & .000 \\
\cline { 2 - 4 } & Cramer's V & .476 & .000 \\
\hline N of Valid Cases & 239 & \\
\hline
\end{tabular}

From the obtained results, in the graph (Graph 1), we see that law students have the most represented neutral attitudes $(30.96 \%)$ but equally represented medium negative and medium positive attitudes. Social work students express a moderately positive or positive attitude, and an equally positive and neutral attitude. A chi-square test was used to obtain statistical significance between respondents according to the field of study in relation to attitudes towards migrants and refugees.

32 Babić, G., Djeca bez pratnje u svjetlu migrantske krize u Centru za pružanje usluga u zajednici Zagreb Dugave, Kriminologija i socijalna integracija, Vol. 28, No. 1, 2020, p. 115-132. 
The chi-square independence test (Table 9) showed a significant difference between the study directions of law and social work in relation to attitudes towards migrants and refugees $\mathrm{p}=0,000(\mathrm{p}<0.05)$ with the obtained values of $\mathrm{c} 2(1, \mathrm{n}=$ $239)=0.476, \mathrm{p}=0.000, \mathrm{fi}=0.48$ (Table 10). According to the results, there is a statistically significant difference in the attitudes of law and social work students towards migrants and refugees. Observing the total number of respondents, their opinion is clear who should be helped when talking about migrants and refugees, and the result shows that the attitude of respondents is mostly oriented to help those who come because of the war in their country, $57 \%$ of respondents. Those who come because of poverty and hunger should be helped, $23 \%$ of respondents think. If we compare respondents from the legal profession and social workers, we can see that the result is uniform in attitudes and that respondents are most supportive of helping people coming from war-torn areas. In the part of the survey of attitudes related to providing assistance and support in relation to the status of a foreigner, more than half of the total respondents $57 \%$ think that assistance should be provided to both refugees and immigrants while $28 \%$ of respondents think that help is needed only by refugees. There is a difference in attitudes in relation to the field of study, law students are more supportive of providing support to refugees $36 \%$ and refugees and immigrants $45 \%$, while social work students, $84 \%$ of them choose the category of refugees and immigrants. A significant difference in the total number of respondents, in relation to the study program, arose with the question: Can immigrants successfully integrate into Croatian society?. While most legal respondents believe that they can but only those with a culture similar to ours, most respondents of social work students believe that all immigrants can successfully integrate into society and the community. A significant difference in the attitudes of law students and social work students occurs in the topic of what to do with migrants, so $29 \%$ of law students think that they should be placed in refugee camps until a solution is found, $25 \%$ of them think that they should be sent back to their country of origin while $29 \%$ of them think they need to be integrated into society. Social work students in the majority, $77 \%$, believe that migrants need to be socialized in society and work on their adaptation and integration into the community.

Research conducted on the student population shows that there is a difference in attitudes towards migrants and refugees depending on the field of study and the science to which they belong. Research ${ }^{33}$ has shown that there is a statistically significant difference between students of natural, social and human sciences, with

33 Sabljak, A., Predrasude studenata prema imigrantima: povezanost predrasuda i socijalne distance te promicanje tolerancije u nastavi filozofije, logike i etike, Master's thesis, University of Zagreb, Faculty of Humanities and Social Sciences, 2020. 
a result that shows that students of biomedicine, technical studies and natural sciences show a higher degree of prejudice than students of social sciences and humanities.

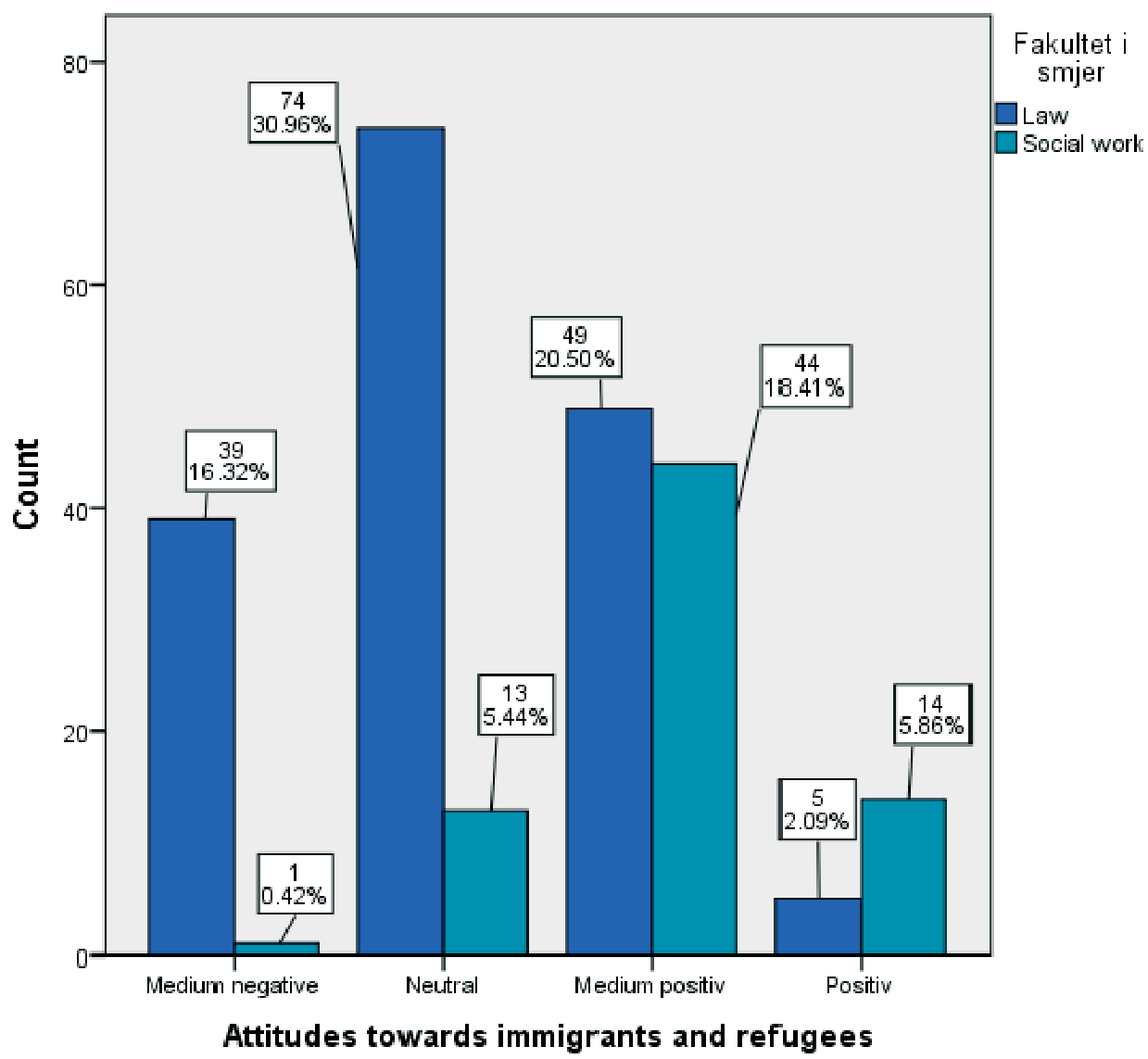

Graph 1: Overview of attitudes towards migrants and refugees of law and social work students

\subsubsection{Respondents' attitudes towards migrants and refugees in relation to political orientation}

One third of the respondents or $35.6 \%$ defined that they do not know their political affiliation, while $28.9 \%$ of the respondents are apolitical, which makes a total of $64.5 \%$ of the respondents. Slightly higher orientation to the right is shown by $14.6 \%$ of respondents compared to the left orientation of $8.4 \%$ of respondents (Table 11). 
Table 11: Political orientation of respondents

Political orientation:

\begin{tabular}{|l|l|l|l|l|l|}
\hline \multicolumn{2}{|c|}{} & Frequency & Percent & Valid Percent & Cumulative Percent \\
\hline \multirow{7}{*}{ Valid } & Extreme right & 2 & .8 & .8 & .8 \\
\cline { 2 - 6 } & Right & 35 & 14.6 & 14.6 & 15.5 \\
\cline { 2 - 6 } & Center & 26 & 10.9 & 10.9 & 26.4 \\
\cline { 2 - 6 } & Left & 20 & 8.4 & 8.4 & 34.7 \\
\cline { 2 - 6 } & Extreme left & 2 & .8 & .8 & 35.6 \\
\cline { 2 - 6 } & Apolitical & 69 & 28.9 & 28.9 & 64.4 \\
\cline { 2 - 6 } & I do not know & 85 & 35.6 & 35.6 & 100.0 \\
\cline { 2 - 6 } & Total & 239 & 100.0 & 100.0 & \\
\hline
\end{tabular}

To obtain statistical significance between respondents according to their political affiliation in relation to attitudes towards migrants and refugees, and in accordance with the third hypothesis, a chi-square test was used according to the result $\mathrm{c} 2(1, \mathrm{n}=239)=0.214, \mathrm{p}=0.017, \mathrm{fi}=0.371$ (Table 12). The result shows a significant difference between the political orientation of the respondents and the attitudes towards migrants and refugees $\mathrm{p}=0,017(\mathrm{p}<0.05)$ (Table 13). The correlation coefficient fi is 0.371 , which according to the Cohen's criteria is considered to be the mean influence between the two variables. Right-wing respondents show the most neutral and moderately positive attitudes towards migrants and refugees, while compared to left-wing respondents, who are exclusively neutral or moderately positive.

Table 12: Overview of statistical data on respondents' attitudes towards political orientation

\section{Chi-Square Tests}

\begin{tabular}{|l|l|l|l|}
\hline & Value & df & Asymp. Sig. (2-sided) \\
\hline Pearson Chi-Square & $32.928^{\mathrm{a}}$ & 18 & .017 \\
\hline Likelihood Ratio & 23.616 & 18 & .168 \\
\hline $\begin{array}{l}\text { Linear-by-Linear As- } \\
\text { sociation }\end{array}$ & .375 & 1 & .540 \\
\hline N of Valid Cases & 239 & & \\
\hline
\end{tabular}

a. 13 cells $(46.4 \%)$ have expected count less than 5 . The minimum expected count is .16. 
Table 13: Display of symmetric measure

Symmetric Measures

\begin{tabular}{|l|l|l|l|}
\hline \multicolumn{2}{|l|}{} & Value & Approx. Sig. \\
\hline $\begin{array}{l}\text { Nominal by } \\
\text { Nominal }\end{array}$ & Phi & .371 & .017 \\
\cline { 2 - 4 } & Cramer's V & .214 & .017 \\
\hline N of Valid Cases & 239 & \\
\hline
\end{tabular}

More negative attitudes of right-wing politically oriented respondents, according to Markaki and Longhi ${ }^{34}$, can be placed in a theoretical framework on antiimmigrant attitudes that includes ideological explanations, while social identity theory links "positive social identification with intragroup and negative evaluation outside groups through social counter identification" ${ }^{35}$. The possibility of a more negative perception of migrants and refugees is related to the characteristics of higher conservatism and lower liberalism. When we talk about political orientation, negative attitudes towards members outside the group can be explained by using the theory of right-wing authoritarianism or the theory of orientation to social domination which link negative attitudes to the perception of threats by migrants and refugees ${ }^{36}$.

\subsubsection{Respondents' attitudes towards migrants and refugees in relation to religious affiliation}

Part of each person's identity is religious identity, so we view identity as identity with ourselves, which includes a sense of belonging to a group, religious community or nation ${ }^{37}$. We can say that religion determines collective and individual identity. If we look at the results of religious affiliation, we see that of the total number of respondents, slightly less than half or $43.5 \%$ think they are religious with the teachings of their religious community, while $37.2 \%$ think they are religious in their own way. Respondents who are not religious or do not know whether they are religious make up $19.3 \%$ of the total number of respondents (Table 14).

34 Markaki, Y.; Longhi, S., What determines Attitudes to Immigration in European Countries? An Analysis at the Regional Level, Norface migrtaion, Discussion Paper No. 32, 2012.

35 Scheepers, P.; Gijsberts, M.; Coenders, M., Ethnic Exclusionism in European Countries. Public Opposition to Civil Rights for Legal Migrants as a Response to Perceived Ethnic Threat, European Sociological Review, Vol. 18, No. 1, 2002, p. 17-34.

36 Gregurović, M.; Kuti, S.; Župarić-Iljić, D., Stavovi prema migrantskim radnicima i tražiteljima azila u istočnoj Slavoniji: dimenzije, odrednice i razlike, Migracijske i etničke teme, Vol. 32, No. 1, 2016, p. 99-122.

37 Cvitković, I., Identitet i religija, Diskursi: društvo, religija, kultura, Vol. I, No. 1, 2011, p. 11-27. 
Table 14: Religious affiliation of the respondents

Religious determination

\begin{tabular}{|l|l|l|l|l|l|}
\hline \multicolumn{2}{|l|}{} & Frequency & Percent & Valid Percent & Cumulative Percent \\
\hline Valid & $\begin{array}{l}\text { I am religious in line with } \\
\text { the teachings of my religious } \\
\text { community }\end{array}$ & 104 & 43.5 & 43.5 & 43.5 \\
\cline { 2 - 6 } & $\begin{array}{l}\text { I am religious in my own } \\
\text { way }\end{array}$ & 89 & 37.2 & 37.2 & 80.8 \\
\cline { 2 - 6 } & $\begin{array}{l}\text { I'm not sure if or not I'm } \\
\text { religious }\end{array}$ & 15 & 6.3 & 6.3 & 87.0 \\
\cline { 2 - 6 } & I'm not religious & 31 & 13.0 & 13.0 & 100.0 \\
\cline { 2 - 6 } & Total & 239 & 100.0 & 100.0 & \\
\hline
\end{tabular}

The results of the relationship between attitudes towards migrants and refugees in relation to religious affiliation were obtained by the chi-square test, in accordance with the fourth hypothesis, and show that there is no statistically significant difference between respondents of different religious affiliation. The result of the chi-square test shows $\mathrm{c} 2(1, \mathrm{n}=239)=0.235, \mathrm{p}=0.154, \mathrm{fi}=0.23$ (Table 16). The result shows that there is no statistically significant difference between respondents who are of different religious affiliation and attitudes of respondents towards migrants and refugees $\mathrm{p}=0.154(\mathrm{p}>0.05)$ (Table 15).

Table 15: Overview of statistical data on respondents' attitudes towards religious determination

Chi-Square Tests

\begin{tabular}{|l|l|l|l|}
\hline & Value & df & Asymp. Sig. (2-sided) \\
\hline Pearson Chi-Square & $13.203^{\mathrm{a}}$ & 9 & .154 \\
\hline Likelihood Ratio & 13.657 & 9 & .135 \\
\hline Linear-by-Linear Association & 7.081 & 1 & .008 \\
\hline N of Valid Cases & 239 & & \\
\hline
\end{tabular}

a. 3 cells (18.8\%) have expected count less than 5. The minimum expected count is 1.19 .

Table 16: Display of symmetric measure

\section{Symmetric Measures}

\begin{tabular}{|l|l|l|l|}
\hline \multicolumn{2}{|c|}{} & Value & Approx. Sig. \\
\hline \multirow{2}{*}{ Nominal by Nominal } & Phi & .235 & .154 \\
\cline { 2 - 4 } & Cramer's V & .136 & .154 \\
\hline \multirow{2}{*}{ N of Valid Cases } & 239 & \\
\hline
\end{tabular}

The majority of respondents declare themselves as being religious in accordance with the teachings of their religious community, but despite this there is no statistically significant difference in attitudes towards migrants and refugees. Research 
by ${ }^{38}$ Gregurović, Kuti and Župarić-Iljić shows that, in addition to political orientation, religious affiliation significantly affects more negative attitudes towards migrants and refugees, and we find the same results in the research of ${ }^{39}$ Marinović Jerolimov and Ančić. Negative attitudes towards migrants from the Middle East were also recorded by researchers (Kunštek, Miškec, Šarić, Šeremet and Štehec, 2016). Contrary to the above research, some research has shown that religiosity was not a significant predictor of any subscale of perceived threats by migrants and refugees ${ }^{40}$ Kalebić Maglica, Švegar and Jovković. It is stated that more religious people, however, are oriented towards content that emphasizes the need for humane treatment of people who need help, which leads to a reduction of negative attitudes towards migrants and the perception of cultural threat.

\section{CONCLUSION}

According to the presented and interpreted results, the first hypothesis was set, $\mathrm{H} 1$ : Female respondents have more positive attitudes towards migrants and refugees than male respondents, is accepted because a statistically significant difference was recorded but with the distance of the possibility of a methodological shortcoming which may be the number of male respondents which is 48 compared to 191 female. The second hypothesis, H2. The field of social work science has a greater impact on the positive attitudes of respondents, compared to the field of law., is accepted because the result shows a statistically significant difference between law students and social work students. The more positive attitudes of social work students can be related to the fact that the social work profession belongs to helping professions and a humanistic vocation aimed at marginalized and deprived groups of people. Hypothesis three, H3. Political orientation on the right influences more negative attitudes towards migrants and refugees, is accepted because there is a statistically significant difference in attitudes towards migrants and refugees in relation to the politically oriented, which is in line with previous research presented in this paper and in accordance with theoretical framework. Fourth hypothesis, H4. Respondents who are more religious have more positive attitudes towards migrants and refugees, are rejected because the results show that there is no statistically significant difference in attitudes towards migrants in relation to

38 Gregurović, M.; Kuti, S.; Župarić-Iljić, D., Stavovi prema migrantskim radnicima i tražiteljima azila u istočnoj Slavoniji: dimenzije, odrednice i razlike, Migracijske i etničke teme, Vol. 32, No. 1, 2016, p.99122.

39 Marinović Jerolimov, D.; Ančić, B., Religioznost i stavovi prema seksualnosti i braku odrasle populacije u Hrvatskoj, Društvena istraživanja, Vol. 23, No. 1, 2014, p. 111-132.

40 Kalebić Maglica, B.; Švegar, D.; Jovković, M., Odnos osobina ličnosti, efekta okvira i stavova prema migrantima, Društvena istraživanja, Vol. 27, No. 3, 2018, p. 495-517. 
the religiosity of the respondents. Research has shown that religious people have a negative but also a positive attitude towards migrants and refugees, depending on the perception of whether they are people who need help or pose a threat. From the presented research results we can confirm that identity factors can influence the creation of attitudes, according to the theoretical framework of the authors Davidov and Semyonov, who link attitudes to the individual level taking into account the country framework. ${ }^{41}$ The results of the research show a positive orientation of attitudes, which indicates a link, according to the authors Markaki and Longhi, an affective attitude that relates to prejudices. ${ }^{42}$ Over $50 \%$ of respondents see immigrants as a cultural threat, which can be linked to previous research in Croatia, Baričević and Koska ${ }^{43}$ and Gregurović, Kuti and Župarić-Iljićc ${ }^{44}$, who obtained similar results. There are also differences between the fields of study, which we can relate to the level of education in the field of human rights. The study, conducted from 2017 to 2019, on a student population of 624 medical students at the universities of Coimbra (Portugal), Melilla (Spain) and Toledo (Spain) shows a similar result. Overall, students, given the helping profession, have a positive attitude toward the immigrant population, while statistically significant differences emerge between universities. ${ }^{45}$ The lack of education in the field of transcultural nursing increases with the more negative attitudes of students.

The shortcomings of the research were noticed in the insufficient representation of male respondents in relation to female, unequal representation of social work students (only undergraduate students are included) in relation to law students. A limitation in the research can be seen in the impossibility of conducting research at all faculties within the University of Osijek as well as in the impossibility of pilot testing. For future research, it would be good to use a larger and random representative sample to get a better generalization of the results. In addition, it would be of great importance to see how pandemic reflected to student attitudes towards migrants. Since we have a thesis that the attitudes towards migrants are

41 Davidov, E.; Semyonov, M., Attitudes toward immigrants in European societies, International Journal of Comparative Sociology, Vol. 58, No. 5, 2017, p. 361.

42 Markaki, Y.; Longhi, S., What determines Attitudes to Immigration in European Countries? An Analysis at the Regional Level, Norface migration, Discussion Paper No. 32, 2012, p. 4.

43 Baričević, V.; Koska, V., Stavovi i percepcije domaće javnosti o nacionalnim manjinama, izbjeglicama $i$ migrantima, Centar za mirovne studije, Zagreb, 2017, p. 14-15.

44 Gregurović, M.; Kuti, S.; Župarić-Iljić, D., Stavovi prema migrantskim radnicima i tražiteljima azila u istočnoj Slavoniji: dimenzije, odrednice i razlike, Migracijske i etničke teme, Vol. 32, No. 1, 2016.

45 Ugarte Gurrutxaga, M. I. et al., Attitudes towards Immigration among Students in the First Year of a Nursing Degree at Universities in Coimbra, Toledo and Melilla, International journal of environmental research and public health, Vol. 17, No. 21, 2020, p. 7977. 
rooted in individual's values and once established they can be resistant to change, we believe that there will be no significant change in this particular area.

The advantage of research examining attitudes towards migrants and refugees in the student population in relation to identity factors in the formation of clearer directions in the educational process of students, focus on a multicultural approach and strengthening the importance and knowledge of the human rights segment.

\section{REFERENCES}

\section{BOOKS AND ARTICLES}

1. Ajduković, D.; Bakić, H.; Stanković, N.; Matić, J., Odnos mladih prema integraciji azilanata, in: Ćubela Adorić, V. et al. (eds.), 25. godišnja konferencija hrvatskih psihologa - Psihologija u promociji i zaštiti ljudskih prava i društvene pravednosti - Sažetci priopćenja, Hrvatsko psihološko društvo, Zagreb, 2017

2. Ajduković, D. et al., Izazovi integracije izbjeglica u hrvatsko društvo: stavovi gradana i pripremljenost lokalnih zajednica. ACT Printlab d.o.o., Zagreb, 2019

3. Cohen, J. W., Statistical power analysis for the behavioral sciences, (2nd ed). Hillsdale, NJ: Lawrence Erlbaum Associates, 1988

4. Cvitković, I., Identitet i religija, Diskursi: društvo, religija, kultura, Vol. I, No. 1, 2011

5. Babić, G., Djeca bez pratnje u svjetlu migrantske krize u Centru za pružanje usluga u zajednici Zagreb - Dugave, Kriminologija i socijalna integracija, Vol. 28, No. 1, 2020

6. Baričević, V.; Koska, V., Stavovi i percepcije domaće javnosti o nacionalnim manjinama, izbjeglicama i migrantima, Centar za mirovne studije, Zagreb, 2017

7. Castells, M.; Cardoso, G., The Network Society. From Knowledge to Policy, Washington, DC: Johns Hopkins Center for Transatlantic Relations, 2005

8. Ceobanu, A. M.; Escandell, X., Comparative Analyses of Public Attitudes Toward Immigrants and Immigration Using Multinational Surve Dana: A Review of Theories and Research, Annual Review of Sociology, Vol. 36, 2010

9. Cohen J., Statistical Power Analysis for the Behavioral Sciences, NY: Routledge Academic, New York, 1988

10. Čačić Kumpes, J.; Gregurović, S.; Kumpes, J., Migracija, integracija i stavovi prema imigrantima u Hrvatskoj, Revija za sociologiju, Vol. 42, No. 3, 2012

11. Davidov, E.; Semyonov, M., Attitudes toward immigrants in European societies, International Journal of Comparative Sociology,, Vol. 58, No. 5, 2017

12. DeVellis, R. F., Scale Development: Theory and Applications, Applied Social Research Methods Series, Vol. 26. Newbury Park, CA: Sage Publications, 1991

13. Dobrotić, I., Posao ili obitelj? Uloga i važnost politika uskladivanja obiteljskih obaveza i plaćenog rada, Kerschoffset d.o.o., Zagreb, 2017

14. Esses, V. M.; Hamilton, L. K., Xenophobia and anti-immigrant attitudes in the time of COVID-19, Group Processes and Integroup Relations, Vol. 24, No. 2, 2012, available on: 
[https://journals.sagepub.com/doi/pdf/10.1177/1368430220983470], Accessed 4 April 2021

15. Gaudagno, L., Migrants and the COVID-19 pandemic: An initial analysis, Internation Organization for Migration, 2020, available on: [https://publications.iom.int/system/files/pdf/ mrs-60.pdf], Accessed 5 April 2021

16. Gravetter, F.J.; Wallnau, L.B., Statistics for the Behavioral Sciences [6th ed.], Australia, Belmont, CA : Thomson/Wadsworth, 2004

17. Gregurović, M.; Kuti, S.; Župarić-Iljić, D., Stavovi prema migrantskim radnicima i tražiteljima azila u istočnoj Slavoniji: dimenzije, odrednice i razlike, Migracijske i etničke teme, Vol. 32, No. 1,2016

18. Gregurović, M., et al., Pandemic Management Systems and Migration, Migracijske i etničke teme, Vol. 36, No. 2-3, 2020

19. Halmi, A., Temelji kvantitativne analize u društvenim znanostima - Kvantitativni pristup socijalnom radu, Alinea, Zagreb, 2013

20. Kalebić Maglica, B.; Švegar, D.; Jovković, M., Odnos osobina ličnosti, efekta okvira i stavova prema migrantima, Društvena istraživanja, Vol. 27, No. 3, 2018

21. Markaki, Y.; Longhi, S., What determines Attitudes to Immigration in European Countries? An Analysis at the Regional Level, Norface migration, Discussion Paper No. 32, 2012

22. Gregurović, M.; Kuti, S.; Župarić-Iljić, D., Stavovi prema migrantskim radnicima i tražiteljima azila $u$ istočnoj Slavoniji: dimenzije, odrednice i razlike, Migracijske i etničke teme, Vol. 32, No. 1, 2016

23. Kalebić Maglica, B.; Švegar, D.; Jovković, M., Odnos osobina ličnosti, efekta okvira i stavova prema migrantima, Društvena istraživanja, Vol. 27, No. 3, 2018

24. Mali, J., Starost, emocije in emocionalno delo v domovih za stare, Socialno delo, Vol. 41, No. 6, 2002

25. Marinović Jerolimov, D.; Ančić, B., Religioznost i stavovi prema seksualnosti i braku odrasle populacije u Hrvatskoj, Društvena istraživanja, Vol. 23, No. 1, 2014

26. Sabljak, A., Predrasude studenata prema imigrantima: povezanost predrasuda i socijalne distance te promicanje tolerancije u nastavi filozofije, logike i etike. Master's thesis. University of Zagreb, Faculty of Humanities and Social Sciences, 2020

27. Scheepers, P.; Gijsberts, M.; Coenders, M., Ethnic Exclusionism in European Countries. Public Opposition to Civil Rights for Legal Migrants as a Response to Perceived Ethnic Threat, European Sociological Review, Vol. 18, No. 1, 2002

28. Ugarte Gurrutxaga, M. I. et al., Attitudes towards Immigration among Students in the First Year of a Nursing Degree at Universities in Coimbra, Toledo and Melilla, International journal of environmental research and public health, Vol. 17, No. 21, 2020

29. White, A. I. R., Historical linkages: pidemic threat, economic ris, and xenophobia, The Lancelot, Vol. 395, 2020, available on: [https://www.thelancet.com/journals/lancet/article/PIIS01406736(20)30737-6/fulltext], Accessed 6 April 2021 


\section{WEBSITE REFERENCES}

1. Dennison, J.; Geddes, A., Why COVID-19 does not necessarily mean that attitudes towards immigration will become more negative, International Organization for Migration, 2020, available on: [https://publications.iom.int/books/covid-19-and-transformation-migrationand-mobility-globally-why-covid-19-does-not-necessarily], Accessed 5 April 2021

2. OECD, Policy Responses to Coronovirus (COVID-19), What is the impact of the COVID-19 pandemic on immigrants and their children?, 19 October 2000, availble on: [https:/www. oecd.org/coronavirus/policy-responses/what-is-the-impact-of-the-covid-19-pandemic-onimmigrants-and-their-children-e7cbb7de/], Accessed 5 April 2021

3. Standard Eurobarometer 93, Summer 2020, Firts results: Public opinion in the European Union, available on: [https://data.europa.eu/euodp/en/data/dataset/S2262_93_1_93_1_ ENG], Accessed 15 January 2021

4. Vehovec, P., Covid-19 and enduring stigma: The corona pandemic increases xenophobia and exclusion worldwide, Max-Planck-Gesellschaft, April 27, 2020, available on: [https:/www. mpg.de/14741776/covid-19-and-enduring-stigma], Accessed 5 April 2021 